\title{
Leaf anatomy and ultrastructure in senescing ancient tree, Platycladus orientalis L. (Cupressaceae)
}

\author{
Qianyi Zhou ${ }^{1}$, Zhaohong Jiang ${ }^{2}$, Xin Zhang ${ }^{1}$, Tian Zhang $^{1}$, Hailan Zhu ${ }^{1}$, Bei Cui ${ }^{1}$, Yiming Li ${ }^{1}$, Fei Zhao ${ }^{3}$, Zhong \\ Zhao ${ }^{\text {Corresp. } 1}$ \\ ${ }^{1}$ Key Comprehensive Laboratory of Forestry, College of Forestry, Northwest Agricultural and Forestry University, Yang Ling, Shaanxi, China \\ 2 College of Life Sciences, Northwest Agricultural and Forestry University, Yang Ling, Shaanxi, China \\ 3 Beijing Agricultural Technology Extension Station, Beijing, China \\ Corresponding Author: Zhong Zhao \\ Email address: zhaozhlunwen2010@126.com
}

Platycladus orientalis L. (Cupressaceae) has a lifespan of thousands of years. Ancient trees have very high scientific, economic and cultural values. The senescence of ancient trees is a new research area but is poorly understood. Leaves are the primary and the most sensitive organ of a tree. To understand leaf structural response to tree senescence in ancient trees, experiments investigating the morphology, anatomy and ultrastructure were conducted with one-year leaves of ancient $P$. orientalis (ancient tree $>2000$ years) at three different tree senescent levels (healthy, sub-healthy and senescent) at the world's largest planted pure forest in the Mausoleum of Yellow Emperor, Shaanxi Province, China. Observations showed that leaf structure significantly changed with the senescence of trees. The chloroplast, mitochondria, vacuole and cell wall of mesophyll cells were the most significant markers of cellular ultrastructure during tree senescence. Leaf ultrastructure clearly reflected the senescence degree of ancient trees, confirming the visual evaluation from above-ground parts of trees. Understanding the relationships between leaf structure and tree senescence can support decisionmakers in planning protection of ancient trees more promptly and effectively, by adopting the timely rejuvenation techniques before the whole tree irreversibly recesses. 


\section{Leaf anatomy and ultrastructure in senescing ancient 2 tree, Platycladus orientalis L. (Cupressaceae)}

3

4 5

6

Qianyi Zhou ${ }^{1}$, Zhaohong Jiang ${ }^{2}$, Xin Zhang ${ }^{1}$, Tian Zhang ${ }^{1}$, Hailan Zhu ${ }^{1}$, Bei Cui ${ }^{1}$, Yiming Li $^{1}$, Fei Zhao ${ }^{3}$, Zhong Zhao $^{1 *}$

${ }^{1}$ Key Comprehensive Laboratory of Forestry, College of Forestry, Northwest Agricultural and Forestry University, Yang Ling, Shaanxi, China

${ }^{2}$ College of Life Sciences, Northwest Agricultural and Forestry University, Yang Ling, Shaanxi, China

${ }^{3}$ Beijing Agricultural Technology Extension Station, Beijing, China

"Corresponding Author:

Zhong Zhao ${ }^{1}$

No.3 Taicheng Road, Northwest Agricultural and Forestry University, Yangling, Shaanxi Province, P. R. China. 712100

Email address: zhaozhlunwen2010@126.com, zhaozh@nwafu.edu.cn

\section{Abstract}

Platycladus orientalis L. (Cupressaceae) has a lifespan of thousands of years. Ancient trees have very high scientific, economic and cultural values. The senescence of ancient trees is a new research area but is poorly understood. Leaves are the primary and the most sensitive organ of a tree. To understand leaf structural response to tree senescence in ancient trees, experiments investigating the morphology, anatomy and ultrastructure were conducted with one-year leaves of ancient P. orientalis (ancient tree $>2000$ years) at three different tree senescent levels (healthy, sub-healthy and senescent) at the world's largest planted pure forest in the Mausoleum of Yellow Emperor, Shaanxi Province, China. Observations showed that leaf structure significantly changed with the senescence of trees. The chloroplast, mitochondria, vacuole and cell wall of mesophyll cells were the most significant markers of cellular ultrastructure during tree senescence. Leaf ultrastructure clearly reflected the senescence degree of ancient trees, confirming the visual evaluation from above-ground parts of trees. Understanding the relationships between leaf structure and tree senescence can support decisionmakers in planning protection of ancient trees more promptly and effectively, by adopting the timely rejuvenation techniques before the whole tree irreversibly recesses. 


\section{Introduction}

37 Ancient trees are trees that have lived for hundreds or even thousands of years. Compared with

38

other species, trees have always shown exceptional longevity (Flanary \& Kletetschka 2005). Ancient trees have very high scientific, economic and cultural values (Zhu \& Lou 2013). The ancient forest which is located in the Mausoleum of Yellow Emperor in Shaanxi Province, China is now the largest, best-preserved planted pure ancient forest of Platycladus orientalis L. (Cupressaceae). The world's oldest $P$. orientalis is more than 4,000 years old and is located in the forest (Chang et al. 2012; Zhang et al. 2015). There are 83,000 P. orientalis trees here, more than 30,000 of which are older than 1,000 years. For many years, this forest has been considered a symbol of the long history of the Chinese nation; it is also known as the "soul of the nation" and the "green treasure" composed of "living biological fossils." However, for many reasons, such as climate change and the influence of human activities, the vitality of ancient trees is not optimistic. Many ancient $P$. orientalis trees are sub-healthy or worse. Moreover, there is no simple and effective method for evaluating the senescence degree of these ancient $P$. orientalis. Platycladus orientalis L. (Cupressaceae) is a major tree species for afforestation and reforestation in northern China (Wang et al. 2016). It is used as a reforestation species in vulnerable areas because it shows great resistance to severe environmental stresses such as drought, cold, salt and lack of nutrition (Wang et al. 2005; Zhang et al. 2016). The most impressive characteristic of $P$. orientalis is its extremely high longevity. Many individuals have a lifespan of several thousand years.

The senescence of ancient trees is a new research area but is poorly understood (Kirkwood 2005). The research on plant senescence especially in trees has just started in recent years (Guarente 2014). Although aging and senescence are always mentioned together in animal biology and sometimes used interchangeably, the definition about aging and senescence in plant science are quite different (Leopold 1975). Aging is a key life process along with germination, growth, maturation, and death and is usually accompanied by organ recession and decay. Senescence indicates organismal functional decline or physical recession of individuals (Noodén 1988; Thomas et al. 2003; Hongbao et al. 2014). Senescence can occur in individuals at any age (Hongbao et al. 2014). Therefore, aging is a process, while senescence is a phenomenon affecting individuals.

Trees have an extraordinary long lifespan of more than several thousands of years (Swetnam \& Brown 1992). Some extremely old trees maintain a high degree of vitality (Rajjou \& Debeaujon 2008; Thomas 2013). For a single tree, the growth curve presents a unique three-stage pattern. At the juvenile stage, the growth rate increases after germination until the mature stage. In this period, trees grow fast to be taller, stronger and mature. This stage will last two to tens of years depending on the tree species. In the mature stage, trees maintain high and strong vitality, constantly producing large numbers of seeds, with a rapid metabolism and a constant renewal of roots and leaves. The growth rate remains relatively stable at a quite high level. This period can last hundreds and even thousands of years. In the senescence stage, trees slow their vigorous growth to a decreased growth rate. This period is very fast compared to the entire lifespan of

Peer] reviewing PDF | (2018:11:32934:2:1:NEW 6 Mar 2019) 
76 trees, requiring usually just a few years until complete death (Issartel \& Coiffard 2011; Jones et 77 al. 2014). Today, research into tree senescence is mainly focused on two aspects: (1) external 78 reasons for long tree lifespan, such as environmental change or environmental stress leading to

79

80

81

82

83

84

85

86

87

88

89

90

91

92

93

94

95

96

97

98

99

100

101

102

103

104

105

106

107

108

109

110

111

112

113

114

115

tree senescence (Kurepa et al. 2009; Zhang et al. 2015), and (2) internal factors such as genome change or telomere shortening (Norbury \& Hickson 2001; Ally et al. 2010; Song et al. 2011; Chang et al. 2017). Therefore, studies of the longevity traits of trees and their senescence mechanisms are helpful to protect precious ancient trees.

To study the issue of biological senescence, the most critical point is choosing an appropriate and convincing samples (Becker \& Apel 1993). Previous senescence related studies have been greatly influenced by various environmental and genetic factors for each individual. Therefore, to study the senescence-related problems of trees, a combination of tree genetic origins and growing environments can describe the problem more objectively. P. orientalis from the Mausoleum of Emperor Huang forest shares similar genetic backgrounds, environments and climate conditions, with an extensive age structure, representing a valuable sampling population for tree senescence-related research.

Leaves are the primary photosynthetic organs in plants and are the part of the plant that directly communicates with the outside world. For annual plants, leaf senescence is accompanied by plant senescence and promotes plant senescence in return (Dhindsa et al. 1981). However, leaf senescence is not equal to whole plant senescence for trees (Lim et al. 2007). This phenomenon is especially significant for deciduous trees (Quy et al. 2017). Unlike deciduous trees, the canopy of evergreen trees (such as P. orientalis) is not renewed and disappeared every year, but its leaves still undergo metabolism. Senescence causes a number of different physiological and biochemical changes in the leaves, which often result in changes in cellular structure (Hengsheng \& Yaoqing 1998; Qi \& Runze 2010). Leaves' anatomy is mainly associated with plant function (Rossatto \& Kolb 2009) and always changes with environmental changes (Fahn 1986;

Bosabalidis \& Kofidis 2002; Poorter \& Bongers 2006). Leaf cuticle has a close relationship with plant resistance capability including heat, drought and salinity resistances (Riederer \& Schreiber 2001). Chloroplast structure has a significant relationship with photosynthetic function (Chin \& Beevers 1970). The intact ultrastructure of chloroplasts guarantees the normal photosynthetic activity of plant (Kutík et al. 2001; Pechová et al. 2003) because of its protection to chlorophyll, soluble protein, ATP enzyme and PS II center (Kutík et al. 2000; Mitsuya et al. 2000; Yamane et al. 2003).

The leaves of $P$. orientalis are known as scale leaves which are composed of many very small scale-like leaves clinging to small branches in a crossed arrangement (Hamidipour et al. 2011). $P$. orientalis tree's leaf branches have no obvious distinction between the abaxial and adaxial which is totally different from typical bifacial leaves such as those of the Sophora japonica L. tree (Quy et al. 2017). P. orientalis's leaf anatomy has a unique symmetrical structure which can be distinguished from other conifer trees (Hamidipour et al. 2011). However, certain structural strategies associated with plant restrictions such as anatomy and ultrastructure remain poorly understood (Coelho et al. 2013). Researches on plant senescence at the cellular level have been

Peer) reviewing PDF | (2018:11:32934:2:1:NEW 6 Mar 2019) 
116 mainly focused on crops so far (Mitsuya et al. 2000; Yamane et al. 2003; Vičánková \& Kutík

117 2005). Research on leaf structure response to tree senescence is lacking (Bacic et al. 2004). A

118 systematic study of the anatomy and ultrastructure of senescence in ancient trees has not yet been

119 reported.

120 As described above, tree species have a special growth rate curve during their lifespan: the

121 extremely long time of high level growth even with the increasing tree age, and the very short

122 time of senescence until the complete death of the whole tree (Jones et al. 2014). Thus, we

123 hypothesized that there is an unidentified relationship between tree senescence and leaf structure.

124 Therefore, we designed this study to identify the relationship among the cellular anatomy, the

125 ultrastructure and the senescence of ancient $P$. orientalis trees. Our objective was to determine

126 the leaf structural response to tree senescence in ancient $P$. orientalis.

127

128 Materials \& Methods

129 Plant material

130 The ancient forest of $P$. orientalis in the Mausoleum of Yellow Emperor is located on the Loess

131 Plateau, Huangling County, Yan'an City, Shannxi Province, China; latitude $35^{\circ} 34^{\prime} \mathrm{N}$, longitude

$132109^{\circ} 15^{\prime} \mathrm{E}$. The annual average temperature is $9.4^{\circ} \mathrm{C}$, and the annual average precipitation is 596.3

$133 \mathrm{~mm}$, while the average annual evaporation capacity is $487.3 \mathrm{~mm}$. This area has between 1,100

134 and 1,300 annual hours of sunshine, a frost-free period of $170 \mathrm{~d}$, an altitude ranges of $1,100 \mathrm{~m}$ to

$1351,200 \mathrm{~m}$, and a typical temperate continental climate with distinct seasonal features. The forest is

136 a planted pure forest of $P$. orientalis with more than 4,000 years of history according to historical

137 records and scientific research. We set up three $50 \mathrm{~m}$ by $50 \mathrm{~m}$ sample plots. In each plot, we

138 conducted an age investigation and a senescence degree evaluation survey of every single $P$.

139 orientalis tree according to the government records and Table 1.

140 Sampled ancient $P$. orientalis trees (more than 2,000 years old) were selected from three sample

141 plots. After investigation, we identified three experimental groups which included three

142 senescence degrees (healthy, sub-healthy and senescent). In each experimental group, three

143 sample trees were selected from the three plots (Table 2). As shown in Table 2, detailed

144 information for the nine sampled trees are listed, including basic information, site condition and

145 senescence degree of sampled trees. For each sampling tree, five repeats of the one-year-old

146 scale leaf (new scale leaves grown that year) were selected at a uniform time (between 10-12

147 a.m.) on the sunny side, central crown of the tree without disease or damage.

148 Leaf samples were collected in July 2014.

149 Leaf paraffin sectioning

150 Leaves were taken from trees at different senescence levels at the same time. After sampling,

151 samples were fixed in formalin-acetic-acid-alcohol (FAA) fixing solution (5\% formaldehyde, $5 \%$

152 acetic acid and $90 \%$ of $70 \%$ alcohol solution) for three days. They were then dehydrated in

153 graded series of alcohol, infiltrated and embedded in paraffin wax (Sigma 411663, Germany)

154 and prepared for paraffin thin sections (Tosens et al. 2012). The dehydrating agent used in this

155 experiment was an anhydrous ethanol and tertiary butyl alcohol mixture (Gu et al. 2014). The 
156 series of transverse thin sections were obtained using a Leica RM2245 semi-automatic rotary

157 microtome. The thickness of all sections were $8 \mu \mathrm{m}$. Paraffin sections were stained with safranin

158 and fast green dye (Bryan 1955). Samples were observed and images were taken under UOP

159 UB200i microscope (UOP Photoelectric Technology Company, Chongqing, China) and

160 measured with Tucsen image analysis system (Tucsen Photonics, Fuzhou, China). A Tucsen

161 image analysis system (Tucsen Photonics, Fuzhou, China) was used to calculate leaf properties

162 such as cuticle thickness, leaf thickness, epidermis thickness, ratios of palisade parenchyma to

163 spongy parenchyma thickness, mesophyll cell thickness, and resin cavity width. Fifty

164 corresponding cells per group were measured for anatomical analysis.

165 Transmission electron microscopy (TEM)

166 One-year-old leaves were collected from sample trees and sized at width of natural and length of

$1674 \mathrm{~mm}$. Five leaflet replicates from each sampled tree were used for each experimental group. The

168 leaf samples were mixed with a $4 \%$ glutaraldehyde fixing solution for preliminary preservation.

169 Then, they were fixed in $2.5 \%(\mathrm{w} / \mathrm{v})$ glutaraldehyde in $0.1 \mathrm{M}$ phosphate buffer $(\mathrm{pH} 7.3)$

170 overnight $(12 \mathrm{~h})$ at $4^{\circ} \mathrm{C}$. Later, after being washed several times with phosphate buffer $(\mathrm{pH}=7.3)$,

171 post-fixation occurred in a $1 \%$ solution of osmium tetroxide for $4 \mathrm{~h}$ at $4^{\circ} \mathrm{C}$. Dehydration was

172 performed through a graded ethanol series of $30 \%, 50 \%, 70 \%, 80 \%, 90 \%$ and $100 \%$ and

173 completed by propylene oxide immersion. The materials were embedded in the Epon 812 resin

174 (Electron Microscopy Sciences, England). Semi-thin sections of embedded leaf samples were cut

175 on a Leica RM2265 Reichert microtome and initially stained with toluidine blue. Ultrathin

176 sections at $70 \mathrm{~nm}$ were cut on a Leica EM UC7 Reichert Ultratome using a diamond knife and

177 post-stained with uranyl acetate and lead citrate (Kang et al. 1993; Ke et al. 2013). The ultrathin

178 sections on the grid were examined under a Hitachi HT7650 transmission electron microscope

179 (Hitachi Ltd., Tokyo, Japan) operating at $80 \mathrm{kV}$ at different magnifications to obtain the best

180 images. Typically, magnification between 300 and 10,000 was used to observe the ultrastructure

181 of mesophyll cells and cellular organelles such as chloroplasts and mitochondria. Parameters of

182 ultrastructure (cell wall thickness, chloroplast length and width, mitochondria length and width,

183 mitochondria number/cell cross, starch grain length and width, starch grain number/chloroplast)

184 were measured and recorded with 30 independent measurement values for each parameter. Each

185 original data point of cell organelle characteristics was repeated three times.

186 Statistical analysis

187 For anatomical observation and TEM observation, statistical analyses were performed using one-

188 way analysis of variance (ANOVA), and the S-N-K test was used to assess the differences

189 among different experimental groups. The confidence level was set at $95 \%(\mathrm{P} \leq 0.05)$, and the

190 data were displayed as the means \pm standard errors (Mean \pm SD). The statistical analyses were

191 performed using SPSS 21.0 software (SPSS, Chicago, USA). Microscope images were grouped

192 using Adobe Photoshop CS5 software (Adobe Systems, California, USA) and diagram were

193 drawn using CorelDraw X6 software (Corel Corporation, Dublin, Ireland).

194

195

Results 
196 Senescence degree evaluations of sampled $\boldsymbol{P}$. orientalis trees

197 Senescence degree evaluation survey results for three plots showed that the average percentage

198 of ancient $P$. orientalis (only trees older than 2,000 years were included here) at each senescent

199 grade was $13.3 \%$ (grade I), 16.7\% (grade II), 40.0\% (grade III), 23.3\% (grade IV) and 6.7\%

200 (grade V). More than half of the ancient trees were sub-healthy or worse.

201 According to the senescence degree evaluation of trees (shown in Table 1), the senescent

202 condition of 9 sampled ancient trees and their site situation were measured at the same time

203 (Table 2).

204 Pictures of $P$. orientalis representing the three experimental groups are shown in Fig.1. Healthy

205 tree groups (Fig.1a) were grade I, sub-healthy tree groups (Fig.1b) were grade III and senescent

206 tree groups (Fig.1c) were grade V. Seen from the above-ground parts and appearance, healthy $P$.

207 orientalis leaves were green, with complete bark and trunk, with high vitality. Senescent trees

208 have yellow and dark leaf color, hollow and corroded trunks, serious crown loss and serious

209 dieback.

210 Leaf anatomy of $\boldsymbol{P}$. orientalis at different tree senescence degrees

211 Scale leaf anatomical properties of $P$. orientalis at different tree senescence degree are listed in

212 Table 3. Seven parameters were measured for statistical analysis of anatomy.

213 The anatomical character of leaf thickness (Table 3) increased with the decrease in tree growth

214 potential. Leaf cuticle thickness (Table 3) of all the ancient trees decreased with the weakened

215 tree growth potential. Compared to all experimental groups, healthy trees exhibited the thickest

216 cuticle. Cuticle thickness declined $2.53 \mu \mathrm{m}$ from healthy trees to senescent trees. The thickness

217 of epidermis cells (Table 3) decreased from healthy trees to senescent trees in all three groups.

218 Palisade parenchyma cell thickness (Table 3) was much thicker than spongy parenchyma cell

219 thickness in all three experimental groups, but the ratio of palisade/spongy did not show

220 statistically significant differences. Palisade cell thickness had the largest value in senescent trees

221 and the smallest value in sub-healthy trees. The same changes were observed for spongy cell

222 thickness. With the decrease in tree growth potential, the resin cavity (Table 3) increased.

223 The one-year-old scale leaves were easily recognizable on the P. orientalis tree (Fig.2a). There

224 was no obvious difference in leaf morphology and leaf color among one-year-old scale leaves of

225 ancient $P$. orientalis trees with different senescence degrees just in terms of their appearance

226 (Fig.2b, c, d). However, the senescence degree of trees induced obvious anatomical changes in

227 leaf tissues of $P$. orientalis and significantly reduced the integrity of epidermal and mesophyll

228 cells (Fig.2e, f, g). One-year-old leaves of ancient healthy P. orientalis (Fig.2e) trees had a

229 perfect leaf anatomy with a typical symmetrical structure. Its epidermis were composed of a

230 single layer of epidermal cells. These epidermal cells were small, and the epidermis cuticle

231 thickness was significantly different (Table 3). The central vein of the leaf consisted of vascular

232 cells arranged closely. The resin channels were located on opposite sides of the central vein. The

233 mesophyll cells of scale leaves were composed of spongy tissue and palisade tissue which were

234 spaced closely. 
235 With weak tree growth potential, the anatomy changed dramatically. In the sub-healthy tree

236 group (Fig.2f), the resin channels were no longer smooth and round in shape. Although the cell

237 shape of epidermal, palisade tissue and spongy tissue cells was normal, there were empty spaces

238 between cells of parenchyma. The destruction and death of protoplasts, and the breakdown of

239 cell membranes were visible.

240 In senescent tree group (Fig.2g), the integrity of anatomy was lost and the resin ducts broken into

241 irregular shapes. A large number of cavities appeared between mesophyll tissues, and only a

242 small number of palisade cells was identified; most spongy tissue cells had lost their normal

243 structure. The vascular system became disintegrated and fragmented with decreased tree

244 senescence.

245 Leaf ultrastructure of $\boldsymbol{P}$. orientalis at different tree senescence degrees

246 In this research, the size and shape of chloroplasts, mitochondria and starch in chloroplasts of $P$.

247 orientalis at different senescence degrees were observed using transmission electron microscopy.

248 The significant differences in chloroplast, mitochondria and starch are presented in Table 4.

249 Thirty independent mesophyll cells were measured for each parameter.

250 Chloroplast parameters are presented in Table 4. The length of chloroplasts at different

251 senescence degrees ranged from $2.03 \mu \mathrm{m}$ to $4.44 \mu \mathrm{m}$, whereas the width of chloroplasts ranged

252 from $3.55 \mu \mathrm{m}$ to $4.19 \mu \mathrm{m}$. The largest chloroplast length and width were observed in the

253 senescent tree group $(4.19 \mu \mathrm{m}$ and $2.14 \mu \mathrm{m}$, respectively). In the three ancient tree groups,

254 chloroplast length and width showed no significant differences, but the number of chloroplasts

255 per cell cross section in the senescent group was obviously higher than in the healthy and sub-

256 healthy groups. Starch is an accumulation product of photosynthesis in chloroplasts. As shown in

257 Table 4, in the three ancient tree groups, the length of starch grains of healthy trees was slightly

258 higher than in sub-healthy and senescent trees. The number of starch grains declined with

259 senescence degree in ancient trees. Mitochondrial parameters are presented in Table 4.

260 Crossections of mesophyll cells of $P$. orientalis generally had five to ten mitochondria. The

261 highest number of mitochondria per cell cross section was 10.1 for ancient healthy trees. The

262 smallest number of mitochondria per cell cross section was 6.0 for ancient senescent trees. The

263 numbers of mitochondria per cell decreased with weakening tree growth condition. For all three

264 experimental tree groups, the length and width of mitochondria showed no significant

265 differences among groups.

266 The ultrastructure of mesophyll cells and organelles of $P$. orientalis at different tree senescence

267 degrees are shown in Fig.3a, b, c. The main organelles analyzed in this part included cell walls,

268 chloroplast, mitochondria and vacuoles.

269 Cell wall thickness decreased with weakening tree growth potential in ancient trees (Table 4 and

270 Fig.3a, b, c). Healthy trees had the thickest cell wall of all groups $(0.26 \mu \mathrm{m})$, while the cell wall

271 of senescent ancient trees were the thinnest. Moreover, the degree of bending of the cell wall

272 increased with declining tree health.

273 The chloroplasts in the mesophyll cells from healthy $P$. orientalis were located at the cell edge,

274 close to the cell plasma membrane and cell wall (Fig.3a). Most chloroplasts were long rods and 
275 bicuspid shaped. In sub-healthy trees, the distribution of chloroplast had changed (Fig.3b). Some

276 chloroplasts had moved far from the cell plasma membrane, and others were close to the cell

277 wall. However, the distribution of chloroplasts was significantly different in the ancient

278 senescent tree group (Fig.3c). All chloroplasts in mesophyll cells were distributed near the

279 nuclei. None were close to the cell plasma membrane as in healthy tree groups.

280 Vacuoles of mesophyll cells in healthy ancient trees were large, centrally distributed and

281 indivisibly, singly monolithic. Sub-healthy trees had many vacuoles of irregular shape

282 distributed near the plasma membrane.

283 The mitochondria distribution are showed in Fig.3. The relative distribution of mitochondria and

284 chloroplasts significantly differed among cells from trees in different senescence degrees. In

285 healthy tree groups (Fig.3d), mitochondria had abundant cristae and were arranged very close to

286 the chloroplasts. In the sub-healthy tree group (Fig.3e), mitochondria had lost cristae and the

287 distance between mitochondria and chloroplasts was much longer than in healthy trees. In the

288 senescent tree group, mitochondria had lost most cristae and were distributed far from

289 chloroplasts (Fig.3f). Moreover, mitochondria in senescent tree group did not have intact

290 membranes, as shown in the enlarged images of ultrastructure within black rectangles (Fig.3d, e,

291 c). All mitochondria maintained round or oval shape but with significant changes in cristae.

292 These changes showed that trees' degree of senescence had a great impact on the relative

293 distribution of mitochondria and chloroplasts.

294 As the most important organelle of plant mesophyll cells, chloroplast apparently changes with

295 tree senescent condition.

296 P. orientalis in the healthy group generally had an intact, smooth, double-layer chloroplast

297 membrane structure (Fig.4a). The thylakoids had clear, thick stacks and occupied the main

298 interspace of chloroplasts. Low-layered grana lamellae only represented a very small part of the

299 interspace and often appeared as a connection between thick thylakoid stacks. Sub-healthy trees'

300 chloroplast ultrastructure had collapsed synchronously (Fig.4b). The thylakoids still had a

301 relatively intact membrane system and sharp-edged lamellae structure (images in black

302 rectangles in Fig.4b). However, chloroplasts had lost their double-layered membrane structure,

303 and the inner contents had leaked out. The number of thick-layered grana stacks had decreased,

304 while thin-layered grana stacks had increased and took up most of the inner chloroplast space.

305 Thus, the thylakoid lamellae were re-arranged from order to disorder when tree growth potential

306 declined from health to sub-health. When tree growth decreased considerably, trees were on the

307 verge of dying and senescence and chloroplasts underwent complete collapse and disintegration

308 (as shown in Fig.4c). The ultrastructural integrity of both the chloroplast membrane system and

309 the thylakoid membrane was completely lost. Grana presented huge bends and degradation and

310 boundaries between layers, and stacks were fuzzy and illegible. The inclusion of chloroplast had

311 completely diffused to the cytoplasm and the starch granules had remained as large particles.

312 Osmiophilic granules were the combination of lipid droplets, proesters, ketones and osmium

313 tetroxide (Stifel et al. 1968). These stroma-distributed small particles in chloroplasts significantly

314 differed during the tree senescence process. In healthy mesophyll cell chloroplasts of ancient 
315 trees (Fig.4d), lipid droplets sizes were small and evenly distributed in the chloroplast stroma.

316 With weakening tree growth condition, in chloroplasts in sub-healthy trees (Fig.4e), the

317 distribution of lipid droplets began to concentrate in some regions of the stroma. Moreover, the

318 number of lipid droplets in sub-healthy trees' chloroplasts increased sharply compared with

319 healthy trees. When trees were senescent, the whole chloroplast lost its structural integrity

320 (Fig.4c, f). lipid droplets leaked out to cell cytoplasm with the extreme deformed thylakoid

321 lamellae fractions and chloroplast inclusions.

322 Most chloroplasts had apparent starch grains. The number of starch grains in chloroplasts

323 changed significantly (as shown in Table 4). Ancient healthy trees had the most starch grains

324 (1.8 starch grains/chloroplast). Most chloroplasts in the other two experimental groups had 1 to 2

325 starch grains per chloroplast. The starch grains were generally huge. In all three groups, starch

326 grains in chloroplasts were distributed in the gap space between grana stacks. There were

327 obvious differences among groups. In ancient healthy tree group, chloroplasts and thylakoid

328 stacks were maintained intact. The presence of starch grains did not affect the normal

329 ultrastructure and integrity of chloroplasts. In the sub-healthy (Fig.4e) and senescent (Fig.4f) tree

330 groups, starch grains pressured and even damaged chloroplasts. In summary, starch grains and

331 lipid droplets changed significantly among different tree senescence degrees.

332 The recession degree of the ancient $P$. orientalis showed consistency with the quality of leaf

333 ultrastructure.

334

335 Discussion

336 Here, we studied the following main features in one-year-old leaf structure of ancient $P$.

337 orientalis with varying tree senescence degree: (a) anatomical parameter properties and structure

338 of leaf tissue; (b) ultrastructure properties and cellular ultrastructure of mesophyll cells.

339 Chloroplasts, mitochondria and vacuoles were the most vital organelles of mesophyll cells

340 during the senescence of trees according to our research. Combining observations of leaf

341 morphological features, anatomy and ultrastructure of trees under different senescence degrees,

342 there were significant structural differences among trees at different senescence degrees.

343 Leaf senescence is not equal to whole plant senescence for trees (Lim et al. 2007). This

344 phenomenon is especially significant for deciduous trees such as Sophora japonica (Quy et al.

345 2017). Unlike deciduous trees, the canopy of evergreen trees (such as P. orientalis) is not

346 renewed and disappeared every year, and the leaves still undergo metabolism. Since leaves from

347 previous years can not reflect the whole tree senescence because of their own structural changes,

348 the well-developed one-year-old leaves with intact anatomy are the best choice to study the leaf

349 structural response to tree senescence (Gepstein 2004).

350 Leaves are the largest organ of trees that is exposed to the environment. During tree longevity,

351 tree senescence degree is vulnerable to environmental factors such as altitude, temperature,

352 rainfall, and soil condition and nutrients (Wimmer 2002; Peguero-Pina et al. 2017). The internal

353 physiology and gene expression are also affected (Zhang et al. 2015; Chang et al. 2017). These

354 factors can impart regular and obvious morphological and structural changes to the leaves of 
355 trees. The structural response can be used to evaluate the overall recession of ancient trees,

356 which can be improved by timely and effective rejuvenation methods.

357 Tree senescence caused obvious changes in leaf cellular structure. The senescence degree of the

358 tree determined the whole tree's morphology. The senescence of the whole tree is reflected in its

359 leaves (Lim et al. 2007). Senescent $P$. orientalis showed a visible decline in appearance

360 including dead branches, a lower density of leaves, yellow foliage, damaged bark and poor

361 growth potential.

362 The leaf anatomy changed with tree senescence. The significant anatomical structural

363 characteristics of senescent $P$. orientalis included thinner cuticles, decreased epidermal

364 thickness, a wide resin cavity, increased leaf thickness and irregular changes in spongy and

365 palisade parenchyma cell thickness. The cuticle thickness is closely related to the relative water

366 content of leaves. The thick cuticle helps plants to withstand drought and other abiotic stresses

367 (Riederer \& Schreiber 2001; Yao et al. 2001). Moreover, the plant epidermis is a multifunctional

368 tissue playing important roles in relations, defense and pollinator attraction (Glover 2000). The

369 senescent $P$. orientalis had thinner cuticles and thinner epidermal thickness which may indicated

370 poor environmental resistant ability of the whole tree. The leaf resin canal is a mature leaf

371 organizational structure, and the resin acids are helpful for trees to resist diseases, pests and fungi

372 (Franich et al. 1983; Rocchini et al. 2010). However, the too wide and disordered structure of

373 resin channels in senescent trees seriously affected the number and distribution of leaf mesophyll

374 cells (spongy and palisade parenchyma cells), which could lead to the decline of the

375 photosynthetic ability of trees (Lawson et al. 2003). These changes fully demonstrate that the

376 physiological function of trees is closely related to their anatomy. Similar results were obtained

377 for anatomical changes of Citrus trees with boron toxicity (Shao et al. 2014), for which a

378 significant change was observed in leaf cortex cells and phloem tissue. The spongy parenchyma

379 cells and palisade parenchyma cells were void and distorted (Shao et al. 2014). Leaf cuticle is

380 mainly associated with plants' capability to resist environmental stress such as drought, salinity,

381 and heat.

382 Leaves' ultrastructure also changed with tree senescence. All the ancient healthy P. orientalis

383 had sharp-edged mitochondria, thickly stacked thylakoids in crescent-shaped intact chloroplasts,

384 a large central vacuole, a large number of chloroplasts, fairly close chloroplast and mitochondria

385 and regular cell walls. In ancient senescent trees, the ultrastructure of mesophyll cells lost its

386 normal structure. The mitochondria cristae were small. The grana stacks were thin and obviously

387 deformed. The chloroplasts were cracked and were far from mitochondria. The vacuoles were

388 broken and decentralized. And cell walls were thin and bent. Chloroplasts are the most sensitive

389 organelle within mesophyll cells. When plants reach senescence, chloroplasts degrade and

390 dismantle before other organelles, leading to a decreased photosynthetic rate (Hörtensteiner \&

391 Feller 2002; Saco et al. 2013). In Vlčková's study of the ultrastructure of senescent leaves, the

392 control leaf chloroplast shapes were oval, organized and equally close to the cell wall and the

393 thylakoid layer structure was clear. Senescent leaf chloroplasts were suborbicular and farther

394 away from the edges of the cell wall; the thylakoid layer structure was unclear, with many starch 
395

396

397

398

399

400

401

402

403

404

405

406

407

408

409

410

411

412

413

414

415

416

417

418

419

420

421

422

423

424

425

426

427

428

429

430

431

432

433

434

grains accumulated in the chloroplast (Vlčková et al. 2006). Normally, starch in senescent tree leaves suggest less effective photosynthesis compared to healthy trees. In our experiment, mitochondria, the other important organelle in mesophyll cells, showed significant structural decline during tree senescence, contradicting to the experiment in which mitochondria remained functional during plant senescence (Hörtensteiner \& Feller 2002). Nevertheless, our results agreed with those of Balaban (Balaban et al. 2005). Mitochondria have a close relationship with senescence according to the free radical theory (Shigenaga et al. 1994). Reactive oxygen species (ROS) contribute to senescence in both animals and plants (Trifunovic et al. 2004; Guo \& Crawford 2005; Noctor et al. 2007). ROS generated in cells arise in a variety of ways. Among all oxidative burdens from several cell sources, mitochondria take on the vast majority of cellular ROS burden (estimated at approximately 90\%) (Turrens 2003). In senescent plants, mitochondria accumulate large amounts of ROS, which might damage mitochondrial cristae, decrease mitochondrial energy production rate and the metabolism of the mesophyll cell, leaf tissue, or the whole plant (Nemoto et al. 2000). Most current research on mitochondria ultrastructure and functional changes has been concentrated in algae, crops and model plants such as Arabidopsis thaliana (Romo-Parada et al. 1991; Xu et al. 2013; Romanova et al. 2016; Fanello et al. 2017). Woody plants such as $P$. orientalis are completely unstudied in this area. Therefore, the important identified markers of tree senescence in leaf ultrastructure included chloroplast, thylakoid, relative distribution between chloroplast and mitochondria, starch grains, lipid droplets and cell wall according to the observation.

According to the current findings, we built a senescence model of cellular structure change in ancient trees (as shown in Fig.5). Tree senescence is caused by many factors, which can be divided into internal factors (including gene regulation, species longevity, etc.) and external factors (including environmental stress, human interference, lack of nutrients, damage by disease and insect). Tree senescence changes the cellular structure. The changed cell structure accelerates the rate of senescence of the whole tree in turn. The collapse of the palisade parenchyma cells, spongy cells, epidermal cells, lipid droplets and starch grain accumulation and collapse of chloroplast and mitochondria all accelerates tree senescence. Moreover, cell structure has a close connection with cell function. Chloroplast and mitochondria structure, play a very important role in tree photosynthetic function and growth condition. As a result, when the tree has undergone cellular collapse of the one-year-old leaves, it can only survive for a short time before total death, whereas a healthy tree not only has strong vitality but can also live for a long period even longer than thousands of years. Interestingly, according to our many years of observation, the ancient $P$. orientalis with the significantly changed cell structure were declining and senescing at an alarming rate. These realities were compatible with our research results. Currently, the majority of ancient $P$. orientalis in Mausoleum of Emperor Huang, Huangling County, Yan'an City, Shaanxi Province, China, are sub-healthy. Very few of the ancient trees are completely healthy, but dying trees also represent only a minority. Thus, timely and effective rejuvenation and protection before most ancient trees in this forest undergo irreversible deterioration is necessary. As these ancient trees represent a precious historical heritage for both 
435 scientific research and culture, improving their growth potential and retaining their germplasm

436 resources is urgent.

437 The relationship between tree senescence and tree leaf structure can support the decision making 438 of when and how to apply rejuvenation techniques such as nutritional supplement, tree pruning,

439 disease control, soil renewal. Moreover, the observation of leaf structure can indicate tree vitality 440 in advance without damage to the precious ancient tree.

441 Senescence is the final stage of a tree before death and it is determined by complex ecological 442 environmental impacts and internal causes over long periods. Factors leading to tree senescence 443 include structural change, environment stress, physiological function, biochemistry metabolism 444 and gene regulation. Structure is only the first step of the study, and further research will involve 445 additional experiments (including environmental, physiological, biochemistry, protein and genetic). At present, it is difficult to obtain comprehensive sampling of ancient trees. The accurate age of ancient trees is difficult to determine. Sampling and analysis are difficult because of specificity. Most areas with ancient trees lack relevant data records. For these reasons, current research on tree aging and tree senescence is rare. In future studies, the deep mechanism of structural response to tree senescence will be investigated.

451

\section{Conclusions}

453 The present research studied the leaf structural response of $P$. orientalis (including morphology, anatomy and ultrastructure) to tree senescence. Observations showed that the senescence of trees significantly changed anatomy and ultrastructure of new-grown leaves. The ultrastructure of chloroplast, mitochondria, vacuole and cell wall of mesophyll cells were the most significant markers during tree senescence. The recession degree of the ancient $P$. orientalis showed a consistency with the quality of leaf ultrastructure. Leaf structure study proved the visual evaluation from above-ground parts of trees can be regarded as a quick and efficient way to characterize the senescence degree of trees.

\section{Acknowledgements}

It is much appreciated that the Key Laboratory of Agriculture in Arid Areas of Northwest 


\section{References}

471 Ally D, Ritland K, and Otto SP. 2010. Aging in a long-lived clonal tree. PLoS Biology 8:697-704.

472

473

474

475

476

477

478

479

480

481

482

483

484

485

486

487

488

489

490

491

492

493

494

495

496

497

498

499

500

501

502

503

504

505

506

507

508

509

510

511

512

513

514

515

516

517

518

Bacic T, Ljubesic N, Uzarevic Z, Grgic L, and Rosa J. 2004. TEM investigation of tannins and chloroplast structure in needles of damaged silver fir trees (Abies alba Mill.). Acta biologica cracoviensia series botanica 46:145-149.

Balaban RS, Nemoto S, and Finkel T. 2005. Mitochondria, oxidants, and aging. Cell 120:483495.

Becker W, and Apel K. 1993. Differences in gene expression between natural and artificially induced leaf senescence. Planta 189:74-79.

Bosabalidis AM, and Kofidis G. 2002. Comparative effects of drought stress on leaf anatomy of two olive cultivars. Plant Science 163:375-379.

Bryan JH. 1955. Differential staining with a mixture of safranin and fast green FCF. Stain technology 30:153-157.

Chang E, Shi S, Liu J, Cheng T, Xue L, Yang X, Yang W, Lan Q, and Jiang Z. 2012. Selection of reference genes for quantitative gene expression studies in Platycladus orientalis (Cupressaceae) using real-time PCR. PLOS ONE 7:e33278.

Chang E, Yao X, Zhang J, Deng N, Jiang Z, and Shi S. 2017. De novo characterization of Platycladus orientalis transcriptome and analysis of its gene expression during aging. PeerJ Preprints 5:e2866v2861.

Chin TY, and Beevers L. 1970. Changes in endogenous growth regulators in nasturtium leaves during senescence. Planta 92:178-188.

Coelho VPdM, Leite JPV, Fietto LG, and Ventrella MC. 2013. Colleters in Bathysa cuspidata (Rubiaceae): Development, ultrastructure and chemical composition of the secretion. Flora - Morphology, Distribution, Functional Ecology of Plants 208:579-590.

Dhindsa RS, Plumb-Dhindsa P, and Thorpe TA. 1981. Leaf Senescence: Correlated with Increased Levels of Membrane Permeability and Lipid Peroxidation, and Decreased Levels of Superoxide Dismutase and Catalase. Journal of Experimental Botany 32:93101.

Fahn A. 1986. Structural and functional properties of trichomes of xeromorphic leaves. Annals of Botany 57:631-637.

Fanello DD, Bartoli CG, and Guiamet JJ. 2017. Qualitative and quantitative modifications of root mitochondria during senescence of above-ground parts of Arabidopis thaliana. Plant Science An International Journal of Experimental Plant Biology 258:112.

Flanary BE, and Kletetschka G. 2005. Analysis of telomere length and telomerase activity in tree species of various life-spans, and with age in the bristlecone pine Pinus longaeva. 6:101-111.

Franich RA, Gadgil PD, and Shain L. 1983. Fungistatic effects of Pinus radiata needle epicuticular fatty and resin acids on Dothistroma pini. Physiological Plant Pathology 23:183-195.

Gepstein S. 2004. Leaf senescence-not just a 'wear and tear' phenomenon. Genome biology $5: 212$.

Glover BJ. 2000. Differentiation in plant epidermal cells. Journal of Experimental Botany 51:497.

Gu J, Yang X, Dong X, Wang H, and Wang Z. 2014. Root diameter variations explained by anatomy and phylogeny of 50 tropical and temperate tree species. Tree Physiology $34: 415$.

Guarente L. 2014. Aging research—where do we stand and where are we going? Cell 159:15.

Guo F, and Crawford NM. 2005. Arabidopsis nitric oxide synthase1 is targeted to mitochondria and protects against oxidative damage and dark-induced senescence. The Plant Cell 17:3436-3450. 
519 Hamidipour A, Radjabian T, Charlet DA, and Zarrei M. 2011. Leaf anatomical investigation of

520

521

522

523

524

525

526

527

528

529

530

531

532

533

534

535

536

537

538

539

540

541

542

543

544

545

546

547

548

549

550

551

552

553

554

555

556

557

558

559

560

561

562

563

564

565

566

567

568

Cupressaceae and Taxaceae in Iran. Kärntner Botanikzentrum 18:95 -111.
Hengsheng LDYJC, and Yaoqing CLY. 1998. Some senescence characteristices of the leaf of Pinus taiwanensis. Forest Research 2.

Hongbao M, Young M, and Yan Y. 2014. Aging and senescence. Stem Cells 5:49-53.

Hörtensteiner S, and Feller U. 2002. Nitrogen metabolism and remobilization during senescence. Journal of Experimental Botany 53:927-937.

Issartel J, and Coiffard C. 2011. Extreme longevity in trees: live slow, die old? Oecologia 165:15.

Jones OR, Scheuerlein A, Salguero-Gómez R, Camarda CG, Schaible R, Casper BB, Dahlgren JP, Ehrlén J, García MB, and Menges ES. 2014. Diversity of ageing across the tree of life. Nature 505:169-173.

Kang Z, Li Z, Chong J, and Rohringer R. 1993. Ultrastructure and cytochemistry of haustorium of wheat stripe rust. Acta Mycologica Sinica 13:52-57.

Ke X, Huang L, Han Q, Gao X, and Kang Z. 2013. Histological and cytological investigations of the infection and colonization of apple bark by Valsa mali var. mali. Australasian Plant Pathology 42:85-93.

Kirkwood TB. 2005. Understanding the odd science of aging. Cell 120:437-447.

Kurepa J, Wang S, Li Y, and Smalle J. 2009. Proteasome regulation, plant growth and stress tolerance. Plant signaling \& behavior 4:924-927.

Kutík J, Holá D, Vičánková A, Šmídová M, Kočová M, Körnerová M, and Kubínová L. 2001. The heterogeneity of structural and functional photosynthetic characteristics of mesophyll chloroplasts in various parts of mature or senescing leaf blade of two Maize ( Zea Mays L.) genotypes. Photosynthetica 39:497-506.

Kutík J, Kočova M, Holá D, and Körnerová M. 2000. The development of chloroplast ultrastructure and Hill reaction activity during leaf ontogeny in different Maize (Zea Mays L.) genotypes. Photosynthetica 36:497-507.

Lawson T, Oxborough K, Morison JI, and Baker NR. 2003. The responses of guard and mesophyll cell photosynthesis to $\mathrm{CO} 2, \mathrm{O} 2$, light, and water stress in a range of species are similar. Journal of Experimental Botany 54:1743.

Leopold AC. 1975. Aging, Senescence, and Turnover in Plants. Bioscience 25:659-662.

Lim PO, Kim HJ, and Gil Nam H. 2007. Leaf senescence. Annual Review of Plant Biology 58:115-136.

Mitsuya S, Takeoka Y, and Miyake H. 2000. Effects of sodium chloride on foliar ultrastructure of sweet potato (Ipomoea batatas Lam.) plantlets grown under light and dark conditions in vitro. Journal of Plant Physiology 157:661-667.

Nemoto S, Takeda K, Yu Z-X, Ferrans VJ, and Finkel T. 2000. Role for mitochondrial oxidants as regulators of cellular metabolism. Molecular and Cellular Biology 20:7311-7318.

Noctor G, De Paepe R, and Foyer CH. 2007. Mitochondrial redox biology and homeostasis in plants. Trends in Plant Science 12:125-134.

Noodén LD. 1988. 10-Abscisic acid, auxin, and other regulators of senescence. Senescence \& Aging in Plants 3:329-368.

Norbury CJ, and Hickson ID. 2001. Cellular responses to DNA damage. Annual Review of Pharmacology and Toxicology 41:367-401.

Pechová R, Kutík J, Holá D, Kočová M, Haisel D, and Vičánková A. 2003. The ultrastructure of chloroplasts, content of photosynthetic pigments, and photochemical activity of Maize (Zea mays L.) as influenced by different concentrations of the herbicide amitrole. Photosynthetica 41:127-136.

Peguero-Pina JJ, Sancho-Knapik D, and Gil-Pelegrín E. 2017. Ancient cell structural traits and photosynthesis in today's environment. Journal of Experimental Botany 68:1389-1392.

Peer) reviewing PDF | (2018:11:32934:2:1:NEW 6 Mar 2019) 
569

570

571

572

573

574

575

576

577

578

579

580

581

582

583

584

585

586

587

588

589

590

591

592

593

594

595

596

597

598

599

600

601

602

603

604

605

606

607

608

609

610

611

612

613

614

615

616

617

618

619

Poorter L, and Bongers F. 2006. Leaf traits are good predictors of plant performance across 53 rain forest species. Ecology 87:1733-1743.

Qi ZYCRZ, and Runze ZGLYG. 2010. Physiological indexes applied to characterize aging old trees. Scientia Silvae Sinicae 3:022.

Quy NV, Zhou Q, and Zhao Z. 2017. Cytokinin ameliorates the abiotic stress severity in chinese scholartree (Sophora Japonica L.) through regulation of chlorophyll fluorescence, antioxidative response and proline metabolism. Research Journal of Biotechnology 12:11-18.

Rajjou L, and Debeaujon I. 2008. Seed longevity: survival and maintenance of high germination ability of dry seeds. Comptes Rendus Biologies 331:796-805.

Riederer M, and Schreiber L. 2001. Protecting against water loss: analysis of the barrier properties of plant cuticles. Journal of Experimental Botany 52:2023-2032.

Rocchini LA, Lindgren BS, and Bennett RG. 2010. Effects of resin flow and monoterpene composition on susceptibility of lodgepole pine to attack by the Douglas-fir pitch moth, Synanthedon novaroensis (Lep., Sesiidae). Journal of Applied Entomology 124:87-92.

Romanova AK, Semenova GA, Ignat'ev AR, Novichkova NS, and Fomina IR. 2016. Biochemistry and cell ultrastructure changes during senescence of Beta vulgaris $\mathrm{L}$. leaf. Protoplasma 253:719-727.

Romo-Parada L, Vézina LP, Charest PM, Castaigne F, and Willemot C. 1991. Effect of modification of storage atmosphere on phospholipids and ultrastructure of cauliflower mitochondria. Physiologia Plantarum 83:664-674.

Rossatto DR, and Kolb RM. 2009. An evergreen neotropical savanna tree (Gochnatia polymorpha, Asteraceae) produces different dry-and wet-season leaf types. Australian Journal of Botany $57: 439-443$.

Saco D, Martin S, and San Jose P. 2013. Vanadium distribution in roots and leaves of Phaseolus vulgaris: morphological and ultrastructural effects. Biologia Plantarum:1-5.

Shao Q, Wang H, Guo H, Zhou A, Huang Y, Sun Y, and Li M. 2014. Effects of shade treatments on photosynthetic characteristics, chloroplast ultrastructure, and physiology of Anoectochilus roxburghii. PLOS ONE 9:e85996.

Shigenaga MK, Hagen TM, and Ames BN. 1994. Oxidative damage and mitochondrial decay in aging. Proceedings of the National Academy of Sciences 91:10771-10778.

Song H, Liu D, Li F, and Lu H. 2011. Season and age-associated telomerase activity in Ginkgo biloba L. Molecular Biology Reports 38:1799-1805.

Stifel FB, Vetter RL, Allen RS, and Horner HT. 1968. Chemical and ultrastructural relationships between alfalfa leaf chloroplasts and bloat. Phytochemistry 7:355-364.

Swetnam TW, and Brown PM. 1992. Oldest known conifers in the southwestern United States: temporal and spatial patterns of maximum age. Old Growth Forests in the Southwest and Rocky Mountain Regions USDA Forest Service General Technical Report RM213:24-38.

Thomas H. 2013. Senescence, ageing and death of the whole plant. New Phytologist 197:696711.

Thomas H, Ougham HJ, Wagstaff C, and Stead AD. 2003. Defining senescence and death. Journal of Experimental Botany 54:1127-1132.

Tosens T, Niinemets Ü, Westoby M, and Wright IJ. 2012. Anatomical basis of variation in mesophyll resistance in eastern Australian sclerophylls: news of a long and winding path. Journal of Experimental Botany 63:5105-5119.

Trifunovic A, Wredenberg A, Falkenberg M, Spelbrink JN, Rovio AT, Bruder CE, Bohlooly-y M, Gidlöf S, Oldfors A, and Wibom R. 2004. Premature ageing in mice expressing defective mitochondrial DNA polymerase. Nature 429:417-423.

Turrens JF. 2003. Mitochondrial formation of reactive oxygen species. The Journal of physiology 552:335-344.

Peer) reviewing PDF | (2018:11:32934:2:1:NEW 6 Mar 2019) 
620

621

622

623

624

625

626

627

628

629

630

631

632

633

634

635

636

637

638

639

640

641

642

643

644

645

646

647

648

649

650
Vičánková A, and Kutík J. 2005. Chloroplast ultrastructural development in vascular bundle sheath cells of two different maize (Zea mays L.) genotypes. Plant, Soil and Environment 51:491-495.

Vlčková A, Špundová M, Kotabová E, Novotný R, Doležal K, and Nauš J. 2006. Protective cytokinin action switches to damaging during senescence of detached wheat leaves in continuous light. Physiologia Plantarum 126:257-267.

Wang F, Wu D, Yamamoto H, Xing S, and Zang L. 2016. Digital image analysis of different crown shape of Platycladus orientalis. Ecological Informatics 34:146-152.

Wang JX, Huang BL, Wang MC, and Wang DH. 2005. Sensitivity of Platycladus orientalis young tree to water stress and its transpiration efficiency at different growth stages during annual growth period. Acta Ecologica Sinica 25:711-718.

Wimmer R. 2002. Wood anatomical features in tree-rings as indicators of environmental change. Dendrochronologia 20:21-36.

Xu Q, Chu W, Qiu H, Fu Y, Cai S, and Sha S. 2013. Responses of Hydrilla verticillata (L.f.) royle to zinc: in situ localization, subcellular distribution and physiological and ultrastructural modifications. Plant Physiology \& Biochemistry 69:43-48.

Yamane K, Kawasaki M, Taniguchi M, and Miyake H. 2003. Differential effect of $\mathrm{NaCl}$ and polyethylene glycol on the ultrastructure of chloroplasts in rice seedlings. Journal of Plant Physiology 160:573-575.

Yao Y, Gao X, and Cheng J. 2001. Study on identification of drought-resistance of several apple species.VII.Changes of the growth and the leaf morphological character of young apple trees under the soil drought. Journal of Beijing Agricultural College 16:16-21.

Zhang S, Zhang L, Chai Y, Wang F, Li Y, Su L, and Zhao Z. 2015. Physiology and proteomics research on the leaves of ancient Platycladus orientalis (L.) during winter. Journal of proteomics 126:263-278.

Zhang S, Zhang L, Zhao Z, Li Y, Zhou K, Su L, and Zhou Q. 2016. Root transcriptome sequencing and differentially expressed drought-responsive genes in the Platycladus orientalis (L.). Tree Genetics \& Genomes 12:79.

Zhu L, and Lou A. 2013. Old-Growth Platycladus orientalis as a Resource for Reproductive Capacity and Genetic Diversity. PLOS ONE 8:e56489. 
Figure 1

Ancient $P$. orientalis at different health conditions

(a), Ancient healthy tree; (b), ancient sub-healthy tree; (c), ancient senescent tree. Red arrows in each images present sampled trees. The photograph in the figure was shoot by author Qianyi Zhou.
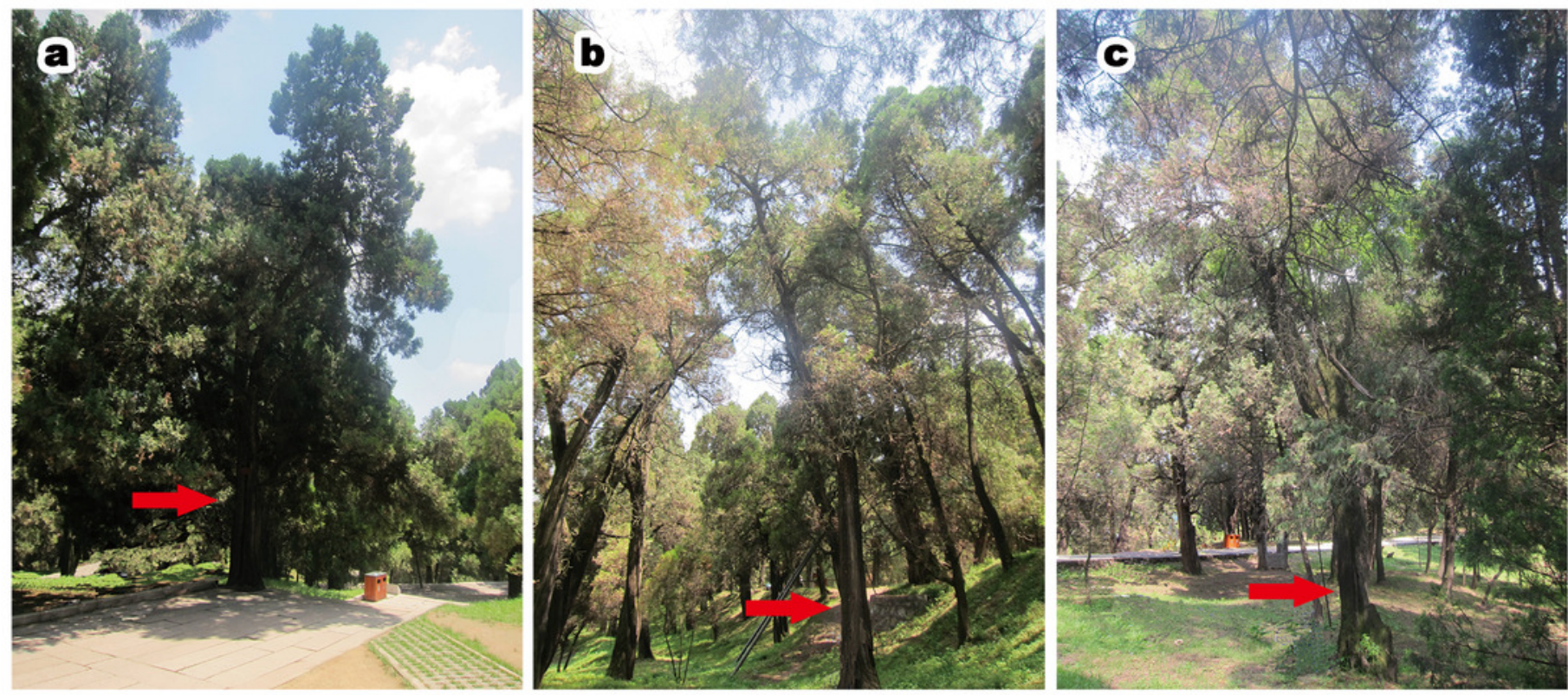


\section{Figure 2}

Morphology and anatomy of one-year-old scale leaf of ancient $P$. orientalis trees with different senescent degrees.

(a) Shows a branch and the red shows arrow one-year-old leaves; leaf morphology of (b) ancient healthy tree, (c) ancient sub-healthy tree and (d) ancient senescent tree; one-yearold leaf anatomy of $(e)$ ancient healthy tree, $(f)$ ancient sub-healthy tree and $(g)$ ancient senescent tree. Image on black rectangle in (b), (c), (d) corresponds to one-year-old scale leaves. Letters in (e), (f), (g) indicating the following: e, epidermis; $p$, palisade mesophyll cell; s, spongy mesophyll cell; v, vein; $r c$, resin channel. Scale bars are $1 \mathrm{~cm}$ in (a), (b), (c), (d) and are $200 \mu \mathrm{m}$ in (e), (f), (g). The photograph in the figure was shoot by author Qianyi Zhou.
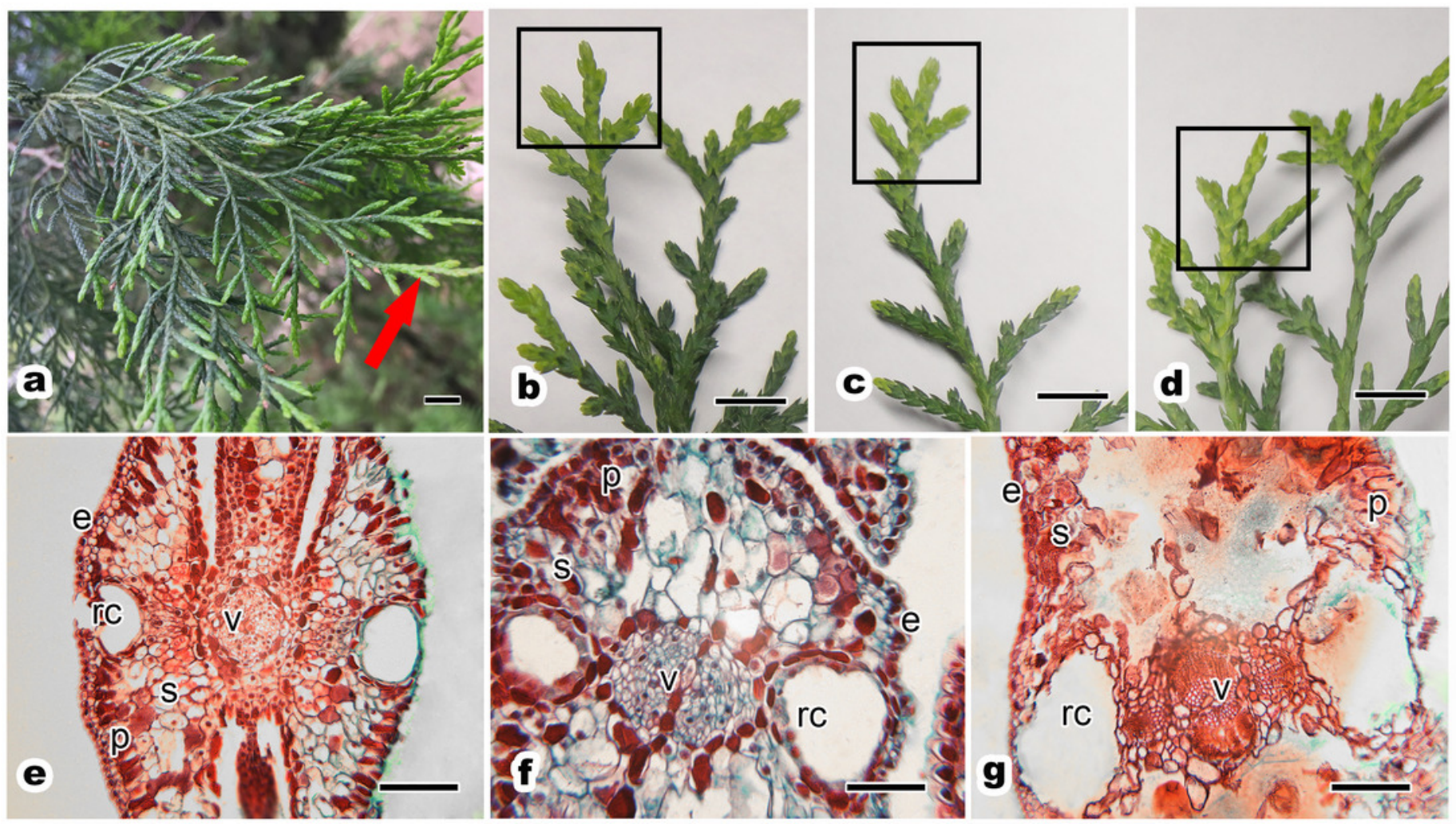


\section{Figure 3}

Ultrastructure of mesophyll cells and organelles, and relative distribution between mitochondria and chloroplasts of $P$. orientalis tree at different senescent states.

(a) and (d), Ancient healthy tree; (b) and (e), ancient sub-healthy tree; (c) and (f), ancient senescent tree. Letters in images represent the following: c, chloroplast; m, mitochondria; $w$, cell wall; v, vacuole; n, nucleus. Image on black rectangle in picture (d), (e) and (f) corresponds to enlarge figure of mitochondria of each experimental group. Scale bars in image (a), (b) and (c) are $2 \mu \mathrm{m}$ and in (d), (e) and (f) are $500 \mathrm{~nm}$.

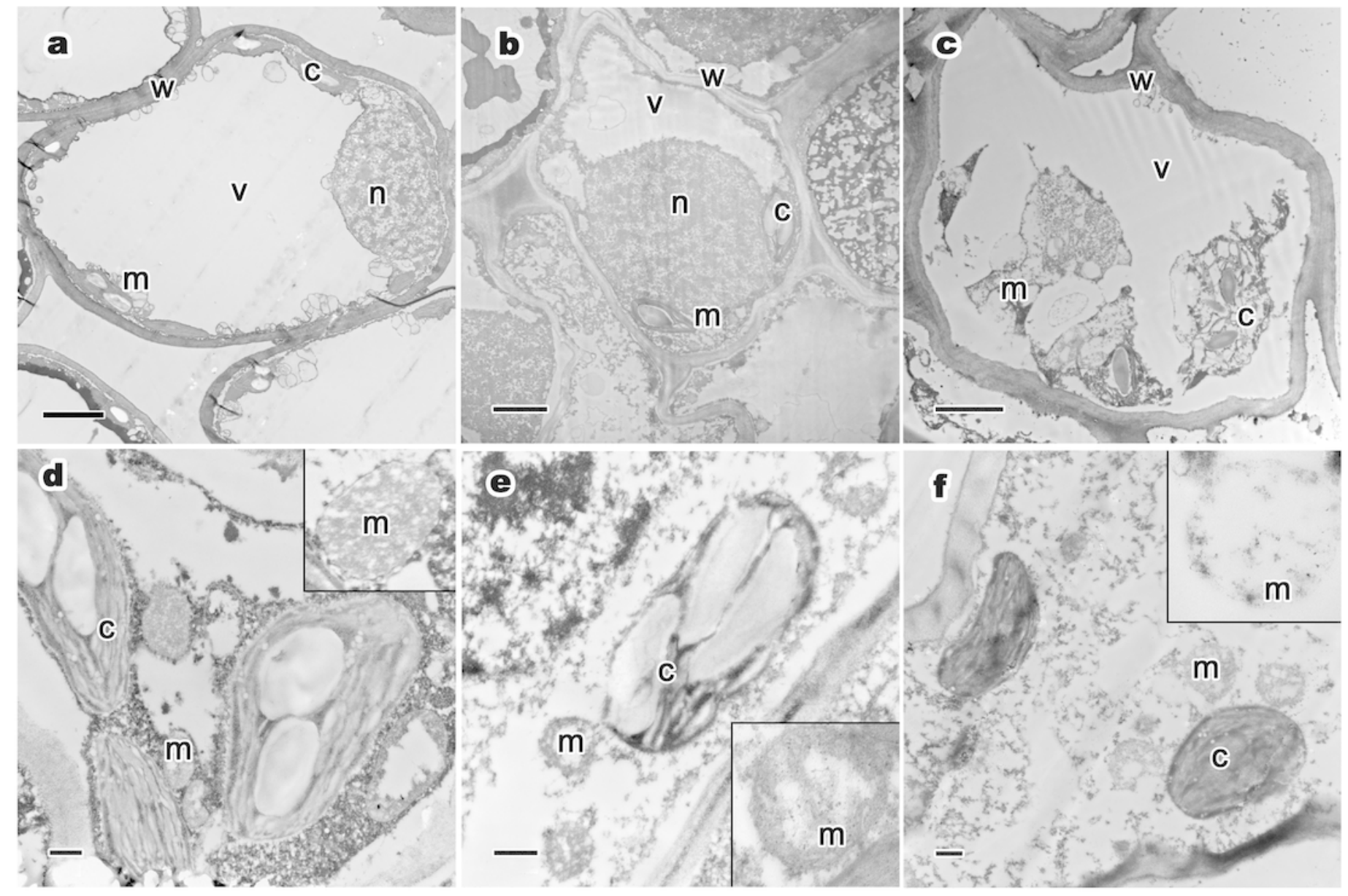




\section{Figure 4}

One-year-old leaf's ultrastructure of chloroplast, lipid droplets and starch grains of $P$. orientalis tree at different tree senescent degrees.

(a) and (d), Ancient healthy tree; (b) and (e), ancient sub-healthy tree; (c) and (f), ancient senescent tree. Letters within images represent the following: c, chloroplast; $t$, thylakoid; $g$, grana lamellae; s, starch grain; I, lipid droplet. Image on black rectangle in picture (a), (b) and (c) corresponds to enlarge figure of chloroplast grana lamellae and thylakoid of each experimental group. Scale bars in all images are $500 \mathrm{~nm}$.

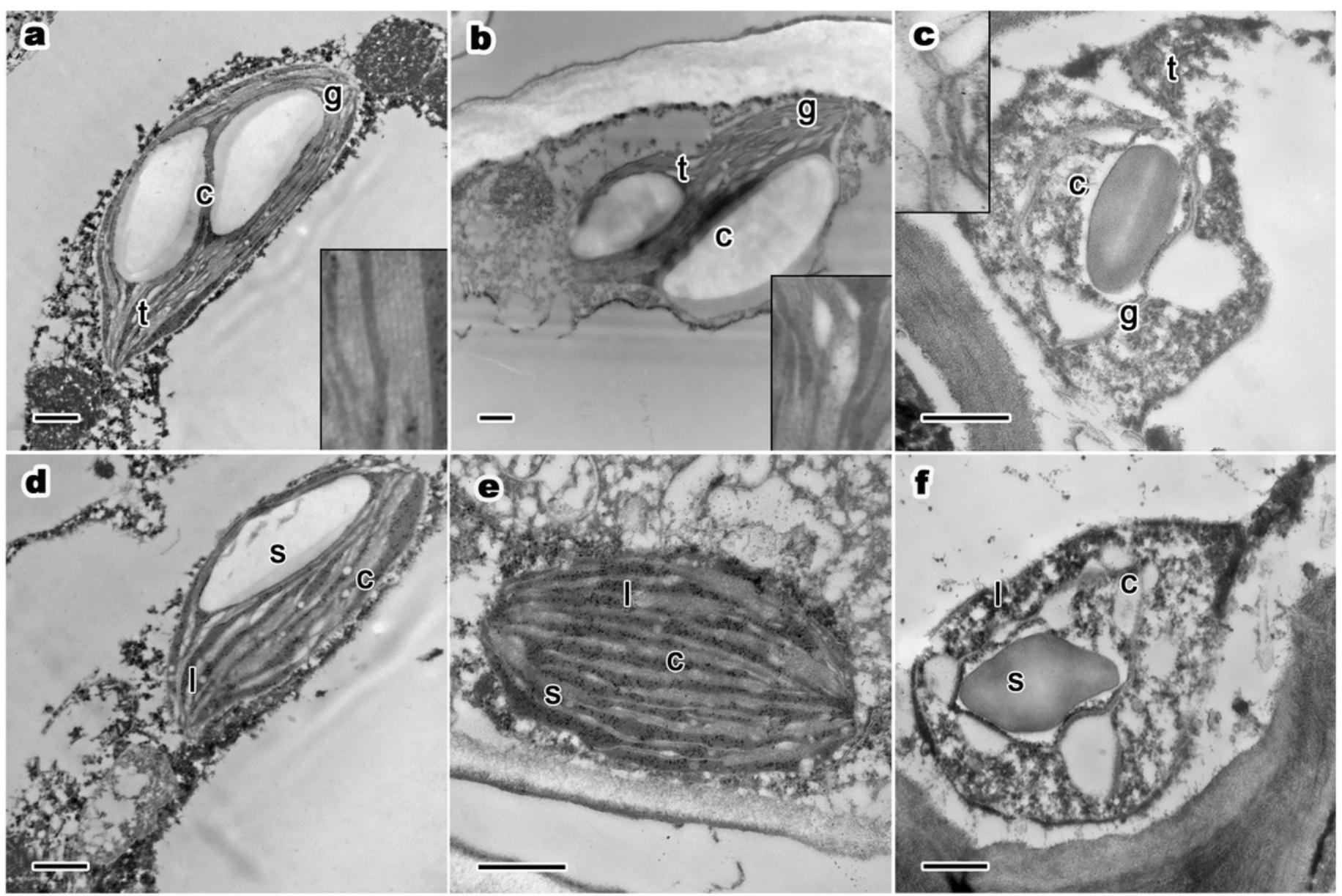


Figure 5

Diagram of leaf cellular structural response to tree senescence.

The left part of the diagram is a mesophyll cell structure diagram of an ancient healthy tree, and the right part of the diagram is a mesophyll cell structure diagram of an ancient senescent tree. 


\section{Ancient $\boldsymbol{P}$. orientalis leaf cellular structure response to tree senescence}

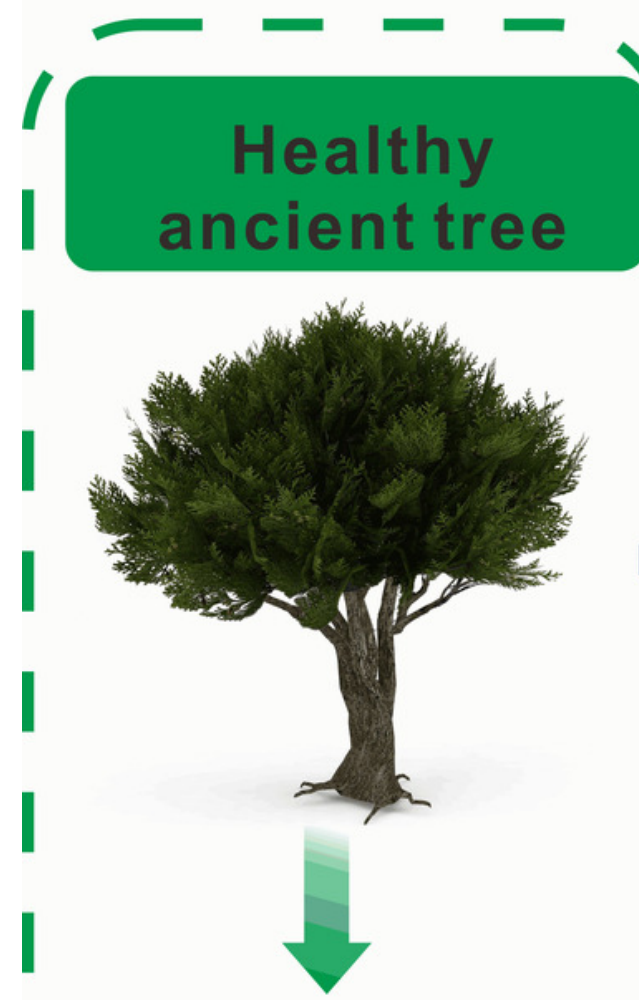

Firm cellular structure

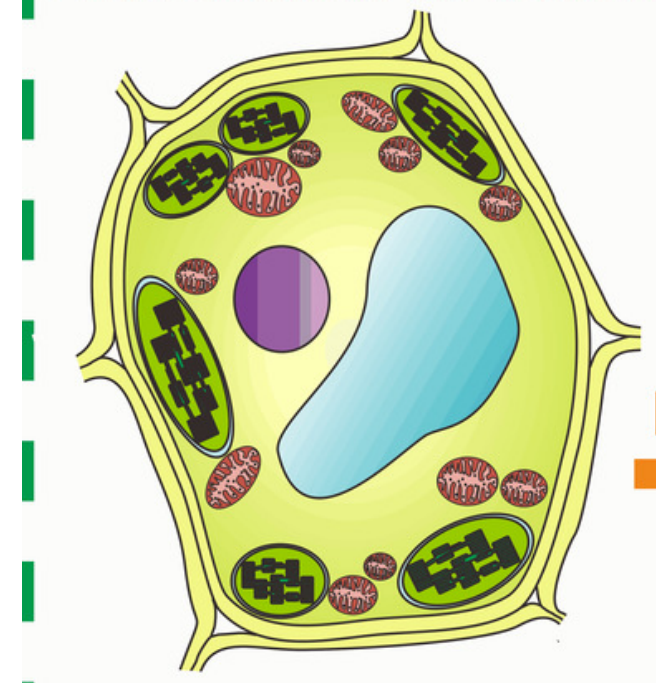

\section{Strong vitality, long-term}

Anatomy:

Thinner cuticle, thinner epidermis,

increasing leaf thickness,

plasmolyzed mesophyll cells

- irregular resin cavity, etc.

\section{Leaf structure change}

Ultrastructure:

Chloroplast integrity loose, mitochondria cristae lost, vacuole breakdown, cell wall twist, etc.

Internal causes:

Senescent ancient tree
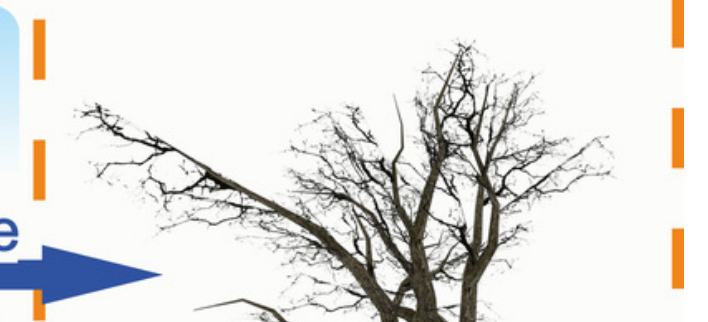

External causes: human disturbance, lack of nutrients, etc.
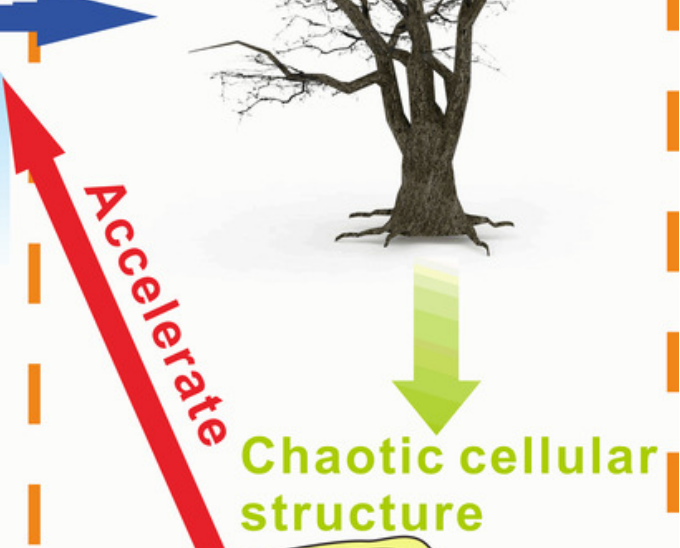

\section{Weak vitality, quick death}




\section{Table 1 (on next page)}

Senescent degree evaluation of trees according to above-ground parts . 
Table 1. Senescent degree evaluation of trees according to above-ground parts.

\begin{tabular}{|c|c|c|c|c|c|c|}
\hline \multirow{2}{*}{$\begin{array}{l}\text { Assessment } \\
\text { items }\end{array}$} & \multicolumn{5}{|c|}{ Evaluation benchmark } & \multirow[t]{2}{*}{ Score } \\
\hline & $\mathbf{0}$ & 1 & 2 & 3 & 4 & \\
\hline Tree vigor & Vigorous growth & Adversely affected & Apparent weakness & Extremely poor & Almost dead & \\
\hline Tree form & Natural tree form & $\begin{array}{l}\text { Nearly natural tree form } \\
\text { but some exceptions }\end{array}$ & $\begin{array}{l}\text { Natural tree form } \\
\text { partially damaged }\end{array}$ & $\begin{array}{l}\text { Natural tree form } \\
\text { damaged and } \\
\text { deformed }\end{array}$ & $\begin{array}{l}\text { Natural tree form } \\
\text { damaged completely }\end{array}$ & \\
\hline Branch access & Normal & $\begin{array}{l}\text { Have a certain but not } \\
\text { obvious influence }\end{array}$ & $\begin{array}{l}\text { Shorter and thinner } \\
\text { branches }\end{array}$ & $\begin{array}{l}\text { Branches extremely } \\
\text { shortened, } \\
\text { internodes inflated }\end{array}$ & $\begin{array}{l}\text { Only have lower } \\
\text { growth branches }\end{array}$ & \\
\hline $\begin{array}{l}\text { Upper branches and } \\
\text { tree apex mortality }\end{array}$ & None & Not obvious & Many & A great many & $\begin{array}{l}\text { No tree apex and } \\
\text { branches }\end{array}$ & \\
\hline $\begin{array}{l}\text { Lower branches } \\
\text { mortality }\end{array}$ & None & Not obvious & $\begin{array}{l}\text { Some and some } \\
\text { broken }\end{array}$ & $\begin{array}{l}\text { Many, mostly } \\
\text { broken }\end{array}$ & $\begin{array}{l}\text { Without healthy } \\
\text { branches }\end{array}$ & \\
\hline $\begin{array}{l}\text { Damage of trunk and } \\
\text { large branches }\end{array}$ & None & $\begin{array}{l}\text { Rarely and has been } \\
\text { restored }\end{array}$ & Obvious & Obvious and broken & The upper part defect & \\
\hline Foliage density & $\begin{array}{l}\text { Branch and leaf } \\
\text { density equilibrium }\end{array}$ & Normal foliage density & Relatively sparse & $\begin{array}{l}\text { Few branches, } \\
\text { sparse }\end{array}$ & Dead branches & \\
\hline Size of leaf buds & $\begin{array}{l}\text { Leaf (bud) is } \\
\text { sufficiently large }\end{array}$ & $\begin{array}{l}\text { Some leaves (bud) } \\
\text { smaller }\end{array}$ & Most buds smaller & $\begin{array}{l}\text { All significantly } \\
\text { smaller }\end{array}$ & $\begin{array}{l}\text { Only a small number } \\
\text { of buds present and } \\
\text { smaller }\end{array}$ & \\
\hline Foliage colors & Almost thick green & Green & $\begin{array}{l}\text { Some obvious } \\
\text { yellow/brown } \\
\text { leaves }\end{array}$ & Almost light green & $\begin{array}{l}\text { All yellow/brown } \\
\text { leaves }\end{array}$ & \\
\hline $\begin{array}{l}\text { Bark damage } \\
\text { (peeled/necrosis) }\end{array}$ & No damage & $\begin{array}{l}\text { Few holes, no } \\
\text { significant damage }\end{array}$ & Old scars & $\begin{array}{l}\text { Wound decayed } \\
\text { significantly }\end{array}$ & $\begin{array}{l}\text { Large hole or severe } \\
\text { peeling }\end{array}$ & \\
\hline Bark metabolism & $\begin{array}{l}\text { Fresh bark, strong } \\
\text { metabolism }\end{array}$ & $\begin{array}{l}\text { Most of the bark fresh, } \\
\text { few locations with weak } \\
\text { individual metabolism }\end{array}$ & $\begin{array}{l}\text { Apparent lack of } \\
\text { vigor, weak } \\
\text { metabolism }\end{array}$ & $\begin{array}{l}\text { Almost all bark } \\
\text { without vigor }\end{array}$ & $\begin{array}{l}\text { Most of the bark } \\
\text { necrotic }\end{array}$ & \\
\hline \multirow[t]{2}{*}{$\begin{array}{l}\text { Germination and } \\
\text { sprouting }\end{array}$} & $\begin{array}{l}\text { Large amount of } \\
\text { foliage, much } \\
\text { germination and } \\
\text { sprouting }\end{array}$ & $\begin{array}{l}\text { Large amount of } \\
\text { foliage, some green } \\
\text { shoots sprouting }\end{array}$ & $\begin{array}{l}\text { Less foliage, fewer } \\
\text { green shoots } \\
\text { sprouting }\end{array}$ & $\begin{array}{l}\text { Little foliage, few } \\
\text { green shoots } \\
\text { sprouting }\end{array}$ & $\begin{array}{l}\text { No germination and } \\
\text { sprouting }\end{array}$ & \\
\hline & \multicolumn{5}{|c|}{ Degree of senescence $=$ Total assessment value/Number of assessment items } & $\begin{array}{l}\text { Final } \\
\text { score }\end{array}$ \\
\hline \multicolumn{7}{|c|}{ * Senescent standards of trees. } \\
\hline Final score & 0.8 & $0.8-1.6$ & $1.6-2.4$ & $2.4-3.2$ & $>3.2$ & \\
\hline Grade & & II & III & $\begin{array}{l}\text { IV } \\
\text { Weak }\end{array}$ & V & \\
\hline
\end{tabular}




\section{Table 2 (on next page)}

Senescent degree and basic information of sampled ancient $P$. orientalis trees. 
1 Table 2. Senescent degree and basic information of sampled ancient $P$. orientalis trees.

\begin{tabular}{|c|c|c|c|c|c|c|c|c|c|c|}
\hline \multicolumn{4}{|c|}{ Basic information of sample trees } & \multicolumn{4}{|c|}{ Site condition of sample trees } & \multicolumn{3}{|c|}{$\begin{array}{c}\text { Senescent degree evaluation survey judgment of } \\
\text { trees }\end{array}$} \\
\hline \multirow{2}{*}{$\begin{array}{c}\text { Government } \\
\text { number of } \\
\text { ancient tree }\end{array}$} & \multirow{2}{*}{$\begin{array}{c}\text { Tree age } \\
\text { (year) }\end{array}$} & \multirow[b]{2}{*}{ Height (m) } & \multirow{2}{*}{$\begin{array}{c}\text { Diameter at } \\
\text { breast height } \\
(\mathrm{mm})\end{array}$} & \multirow[b]{2}{*}{ Altitude (m) } & \multirow[b]{2}{*}{ Slope } & \multicolumn{2}{|c|}{ GPS coordinates } & \multirow[b]{2}{*}{ Grade } & \multirow{2}{*}{$\begin{array}{c}\text { Senescent } \\
\text { degree }\end{array}$} & \multirow[b]{2}{*}{ Sample group division } \\
\hline & & & & & & Longitude (E) & Latitude $(\mathrm{N})$ & & & \\
\hline 00225 & $>2000$ & 13.6 & 640 & 1111 & $33^{\circ}$ & $109^{\circ} 15^{\prime} 42.5^{\prime \prime}$ & $35^{\circ} 35^{\prime} 18.0^{\prime \prime}$ & I & Healthy & Ancient healthy tree \\
\hline 00221 & $>2000$ & 15.9 & 607 & 1112 & $10^{\circ}$ & $109^{\circ} 15^{\prime} 42.1^{\prime \prime}$ & $35^{\circ} 35^{\prime} 18.1^{\prime \prime}$ & I & Healthy & Ancient healthy tree \\
\hline 00228 & $>2000$ & 20.7 & 837 & 1107 & $21^{\circ}$ & $109^{\circ} 15^{\prime} 42.9^{\prime \prime}$ & $35^{\circ} 35^{\prime} 17.7^{\prime \prime}$ & I & Healthy & Ancient healthy tree \\
\hline 00360 & $>2000$ & 17.8 & 640 & 1104 & $17^{\circ}$ & $109^{\circ} 15^{\prime} 42.2^{\prime \prime}$ & $35^{\circ} 35^{\prime} 17.5^{\prime \prime}$ & III & Sub-healthy & Ancient sub-healthy tree \\
\hline 00231 & $>2000$ & 12.5 & 572 & 1109 & $26^{\circ}$ & $109^{\circ} 15^{\prime} 43.0^{\prime \prime}$ & $35^{\circ} 35^{\prime} 17.5^{\prime \prime}$ & III & Sub-healthy & Ancient sub-healthy tree \\
\hline 00333 & $>2000$ & 14.6 & 544 & 1105 & $18^{\circ}$ & $109^{\circ} 15^{\prime} 44.1^{\prime \prime}$ & $35^{\circ} 35^{\prime} 18.0^{\prime \prime}$ & III & Sub-healthy & Ancient sub-healthy tree \\
\hline 00227 & $>2000$ & 17.6 & 550 & 1094 & $35^{\circ}$ & $109^{\circ} 15^{\prime} 43.3^{\prime \prime}$ & $35^{\circ} 35^{\prime} 18.3^{\prime \prime}$ & $\mathrm{V}$ & Senescent & Ancient senescent tree \\
\hline 00362 & $>2000$ & 11.7 & 630 & 1107 & $15^{\circ}$ & $109^{\circ} 15^{\prime} 42.5^{\prime \prime}$ & $35^{\circ} 35^{\prime} 17.2^{\prime \prime}$ & $\mathrm{V}$ & Senescent & Ancient senescent tree \\
\hline 00237 & $>2000$ & 10.6 & 426 & 1103 & $15^{\circ}$ & $109^{\circ} 15^{\prime} 43.7$ & $35^{\circ} 35^{\prime} 17.4^{\prime \prime}$ & $\mathrm{V}$ & Senescent & Ancient senescent tree \\
\hline
\end{tabular}




\section{Table 3 (on next page)}

Anatomical properties of scale leaves of ancient $P$. orientalis at different tree senescent degree.

Data are presented as the mean \pm SD $(n=50)$. Different lowercase letters under the same parameter denote the least significant differences according to the S-N-K test at $\mathrm{P}<0.05$ compared to data with different senescent degree but at the same tree age. 
Table 3. Anatomical properties of scale leaves of ancient $\boldsymbol{P}$. orientalis at different tree senescent degree.

\begin{tabular}{|c|c|c|c|c|c|c|c|c|}
\hline Parameters & & $\begin{array}{l}\text { Leaf thickness } \\
(\mu \mathrm{m})\end{array}$ & $\begin{array}{l}\text { Cuticle } \\
\text { thickness } \\
(\mu \mathrm{m})\end{array}$ & $\begin{array}{l}\text { Epidermis } \\
\text { thickness }(\mu \mathrm{m})\end{array}$ & $\begin{array}{l}\text { Spongy } \\
\text { parenchyma cell } \\
\text { thickness }(\mu \mathrm{m})\end{array}$ & $\begin{array}{l}\text { Palisade } \\
\text { parenchyma cell } \\
\text { thickness }(\mu \mathrm{m})\end{array}$ & $\begin{array}{l}\text { Ratio of } \\
\text { palisade } \\
\text { /spongy }\end{array}$ & $\begin{array}{l}\text { Resin cavity } \\
\text { width }(\mu \mathrm{m})\end{array}$ \\
\hline \multirow{3}{*}{$\begin{array}{l}\text { Ancient } \\
\text { tree }\end{array}$} & Healthy & $387.11 \pm 46.18^{c}$ & $5.68 \pm 1.29^{a}$ & $21.68 \pm 1.78^{a}$ & $36.53 \pm 2.40^{\mathrm{b}}$ & $61.93 \pm 6.23^{b}$ & $1.70 \pm 0.21^{\mathrm{a}}$ & $93.60 \pm 11.25^{c}$ \\
\hline & Sub-healthy & $645.68 \pm 41.79^{b}$ & $3.91 \pm 0.84^{\mathrm{b}}$ & $18.37 \pm 2.04^{b}$ & $30.75 \pm 3.10^{\mathrm{a}}$ & $54.01 \pm 5.90^{c}$ & $1.77 \pm 0.25^{\mathrm{a}}$ & $128.44 \pm 10.09^{b}$ \\
\hline & Senescent & $1009.85 \pm 19.83^{\mathrm{a}}$ & $3.15 \pm 0.75^{\mathrm{c}}$ & $18.74 \pm 2.82^{b}$ & $39.00 \pm 3.90^{\mathrm{a}}$ & $68.56 \pm 7.12^{\mathrm{a}}$ & $1.77 \pm 0.24^{\mathrm{a}}$ & $252.93 \pm 29.21^{\mathrm{a}}$ \\
\hline
\end{tabular}

Data are presented as the mean $\pm \mathrm{SD}(\mathrm{n}=50)$. Different lowercase letters under the same parameter denote the least significant differences according to the $\mathrm{S}-\mathrm{N}-\mathrm{K}$ test at $\mathrm{P}<0.05$ compared to data with different senescent degree but at the same tree age. 


\section{Table 4 (on next page)}

Ultrastructure properties of mesophyll cells of ancient $P$. orientalis at different senescent degree. 
$1 \quad$ Table 4. Ultrastructure properties of mesophyll cells of ancient $\boldsymbol{P}$. orientalis at different senescent degree.

\begin{tabular}{|c|c|c|c|c|c|c|c|c|c|c|}
\hline Ancient tree & $\begin{array}{l}\text { Cell wall } \\
\text { thickness } \\
(\mu \mathrm{m})\end{array}$ & $\begin{array}{l}\text { Chloroplast } \\
\text { length }(\mu \mathrm{m})\end{array}$ & $\begin{array}{l}\text { Chloroplast } \\
\text { width }(\mu \mathrm{m})\end{array}$ & $\begin{array}{l}\text { Chloroplast } \\
\text { number/cell } \\
\text { cross section }\end{array}$ & $\begin{array}{l}\text { Mitochondria } \\
\text { length }(\mu \mathrm{m})\end{array}$ & $\begin{array}{l}\text { Mitochondria } \\
\text { width }(\mu \mathrm{m})\end{array}$ & $\begin{array}{l}\text { Mitochondria } \\
\text { number/cell } \\
\text { cross section }\end{array}$ & $\begin{array}{l}\text { Starch grain } \\
\text { length }(\mu \mathrm{m})\end{array}$ & $\begin{array}{l}\text { Starch grain } \\
\text { width }(\mu \mathrm{m})\end{array}$ & $\begin{array}{l}\text { Starch grain } \\
\text { number/ } \\
\text { chloroplast }\end{array}$ \\
\hline Healthy & $0.26 \pm 0.03^{\mathrm{a}}$ & $3.67 \pm 0.61^{\mathrm{a}}$ & $2.13 \pm 0.71^{\mathrm{a}}$ & $5.3 \pm 1.25^{\mathrm{b}}$ & $0.97 \pm 0.60^{\mathrm{a}}$ & $0.68 \pm 0.32^{\mathrm{a}}$ & $10.1 \pm 2.08^{\mathrm{a}}$ & $2.00 \pm 0.62^{\mathrm{a}}$ & $1.10 \pm 0.53^{\mathrm{a}}$ & $1.8 \pm 0.42^{\mathrm{a}}$ \\
\hline Sub-healthy & $0.21 \pm$ & 3.55 & $1.70=$ & $4 .^{\circ}$ & 0.71 & 0.55 & $8.0 \pm 1.15^{b}$ & $1.49 \pm$ & 0.78 & $.70^{\mathrm{a}}$ \\
\hline Senescent & $0.19 \pm 0.02^{b}$ & $4.19 \pm 1.14^{\mathrm{a}}$ & $2.14 \pm 0.64^{\mathrm{a}}$ & $9.7 \pm 0.95^{\mathrm{a}}$ & $0.67 \pm 0.28^{\mathrm{a}}$ & $0.52 \pm 0.24^{\mathrm{a}}$ & $6.0 \pm 1.15^{\mathrm{c}}$ & $1.54 \pm 0.43^{b}$ & $0.79 \pm 0.30^{\mathrm{a}}$ & $1.0 \pm 0.00^{\mathrm{b}}$ \\
\hline
\end{tabular}

